\title{
Reflexive Manufacturing: Taiwan's Integration in the Global Economy
}

\author{
Crieng-Shlu KaO and Gari G. Hamilton

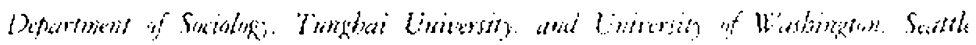

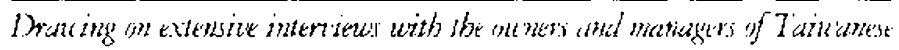

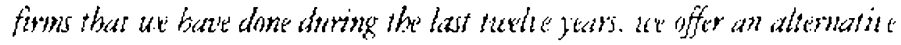
interpretation of Taicumese industrialization. In contrast ath tamomists

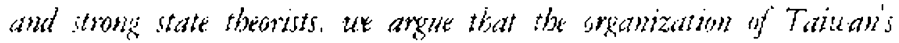

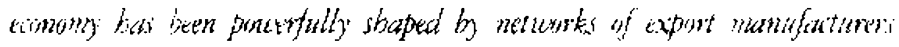

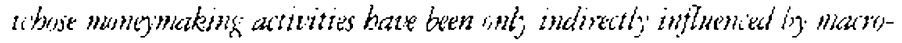

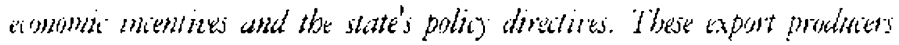

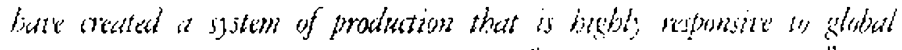

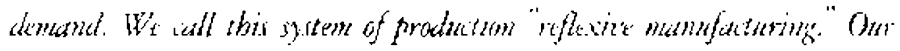
paper traces the detelipment of reflexint mantfatwing in Taisum and demustrates the limited role the state ploned in shoting the onganiation of the Taiwanese ecanomy.

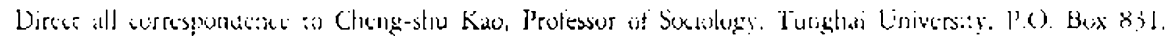

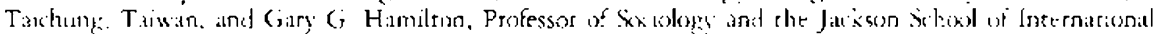

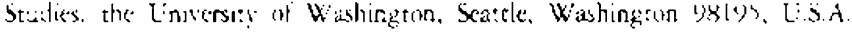




\section{REFLEXIVE MANUFACIURING: IAIWAN'S INTEGRATION IN THE GLOBAL ECONOMY}

$\mathrm{T}$ he adage. "What you see, depends on where you lexk," certainly applies to ibe disciplinary gaze given to explaining Asian (appitalisns. In the past two decades, the leading explanations of Asia's economic ups and downs split between market and state theories, with coomomises generally advocating the former and political scientists the lateer. This incerpretive standuff between disciplinary perspectives cont inues a cintroversy started in other sites, particularly Europe and Latin America. However, with their rapid and pervasive econonic successes, the countries in East and Southeast Asia became the ideal testing grounds for theorics of economic development.

In the 1970s and carly I980s, the empitical observations of economists secmed mos1 perstlasive. Some conomists made bold statements alxout the developmental inevitability of frec markets, while most area-oriented cconomises (T.trte 1979; Sritovsky 1985: Kuo, et.al. 1981; Galenson 1979) gave nuanced explanations that included political and soxial factors, but that nonethaless focused squarely on macro-conemic datainterest and inflation, per capital income, toral factor productivity, bilateral trade fluws, and so forth.

With the publication of Chalmers Johnson's influential book on MI'l (1982), the point of view began to change. Johnson persuasisely argucd that Japan's economic success arosc, not because of free markets, but tacher becalse of the stutc's careful planning and its capacity to implencent those plans within the coonomy. Johnsin's book was followed by a number of important works that generalized his conclusions to orher political regimes, particularly those in Asia. In fact, with the work of Cummings (1984), Deyo (198:), Amsden (1985, 1989), Woo (1991), Wade (194)1), and Lvans (1995), South Korea and Tawan becance the epitome of the developmental state, and other regimes, even the Japanese one, were seer as less successtul versions. Like the ecomomists before them, these political scientists developed nuanced explanations that included a range of other non-political factors, including social and ccononic ones, bue their disciplinary gaze remained centered on the "primacy of politics, as carried our most particularly by a nation's governmental bureaucrats and technoxiats" (Pempel 19)9)

Market economists focus on macro-economic parterns and political conomists on regime. characteristics and industrial policy. Although other factors enter into their explanations at the periphery, what they see is largely a funcion of where they look. Strangely, however, neither set of theorists look squarely at what is, ostensibly, the ebject of alseir investigation- the industrializing economy itself, particularly how the economy is organized and how it apcrates. In his meticulous analysis of the states role in creating 'Tawaris industrial economy, Rokert Wade (1991, 70) confesses this exacr point:

I should stress rhat the organization of firms-their size, the way they grow: their methods of doing business, and the relationships bxtween them-is a major gap in the argunent of this book. Any discussion of an cconomy's development should give a central place to the organization of firms and industries. But sine little evidence is available on this subject for 'Taiwan, and since my primary interest is the uses of public power, 
I sily lett.ce merce allout it.

Buth market and state theories of Asian inciuseral gerewts presuppose. respectively.

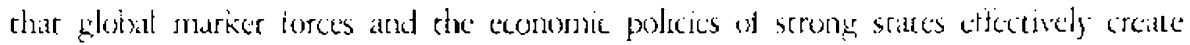

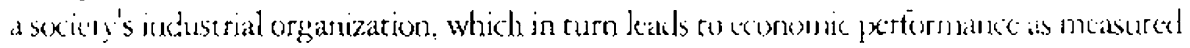

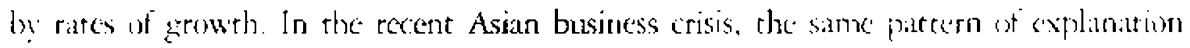

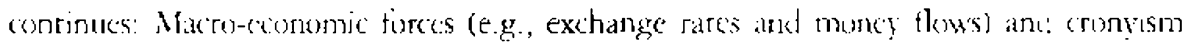

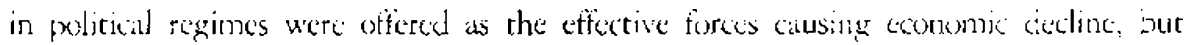
what sutiered and ofter went bankrupt were the ausinesses themselves. In exjlaining lxoth the rise of and the later erisis in Asian economikes. the organization of che comonny.

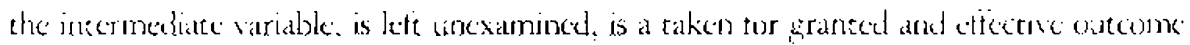
of ele pronkary causes.

$A$ third group of researchers las been examining the orgatrizations and operation of Asian economies. Very broadly, rhese writers congage in what is known as incticurional

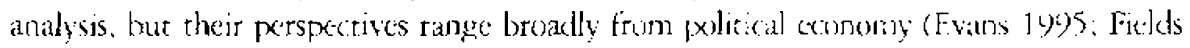

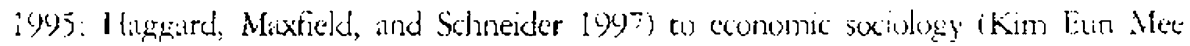
1998; Kim Hyuk-Rae 1993. 199t, 1998 ; Lew 199x; Orru, Biggart anıl Hamilton 1949:

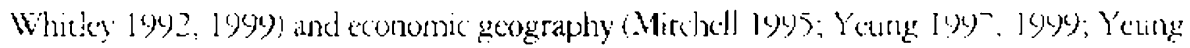

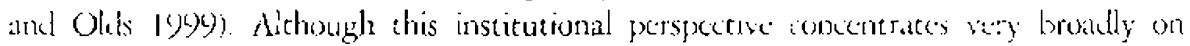

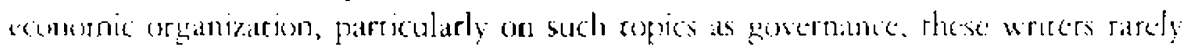

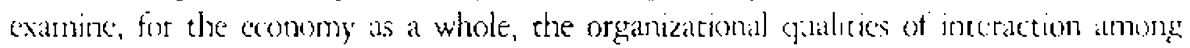
firms. They preter instcad to leok at she insriturional background rather thill at the organizational forcground.

In this paper, we suggest that the organization of market alctivity should rot be secen exclusive'y ir: terms of backgroure? institutional facters or as the exclusite outcome of

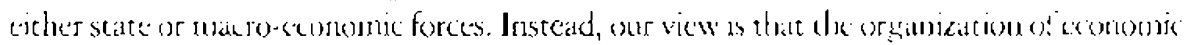
axtivity has emergent features that are not fully accounted for by exengenous taters

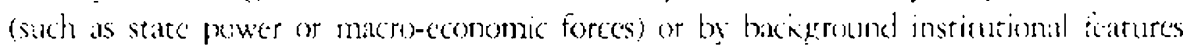

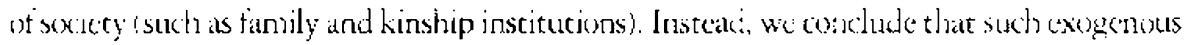
institurional tactors are socially construced and reconsiructed in the context of on-going action, which is intrinsically shaped by the organization of meractions. In ot her words. the frast. as well as the fucure. only has relevarke it: the cuncext of present acciom.

Using rhis organizational perspective, we want as rethink the iundamental st:ature

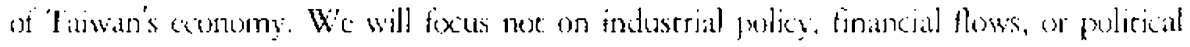

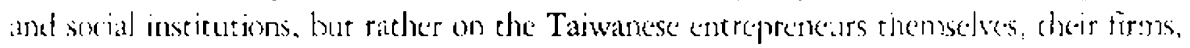

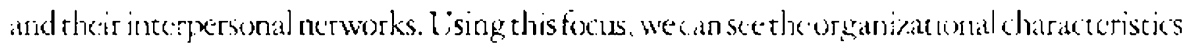
of thes coonomy and can understand the dynamics of this cconomy alpart frome other factors, all of shich are importane in the mix, hut ixoxe of which explain bou che ecoromy grows and changes ever ime.

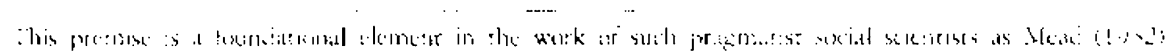

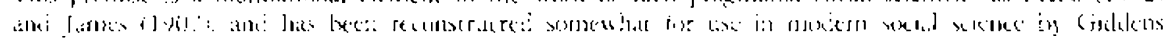

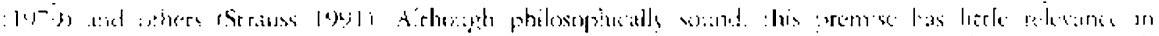

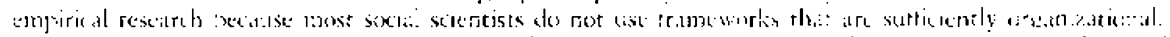

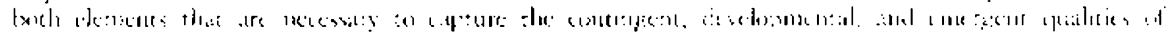

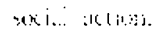


For dhis analysis we draw on the intensive interviews done over a twelve-year period by the research teams of the Institute of Last Asia Societics and Economics (IEASE) at 'lunghai University in Taiwan. These teams interviewed over 600 Taiwanese cnt repreneurs who own or manage firms in Tawan and China. Over fifry entrepreneurs were inrerviewed scveral times. Most interviews lasted for more than two hours and some lasted over four hours. All the interviews have been transcribed.?

Since these interviews cover nearly a fifteen-year period, we cannot treat them as a sample on which we can perform statistical tests. Indeed, it is difficult statistically to compare the same firm at two different points in time, because except for continuity of owners, some radically changed products, networks of colleagues, locations of matufacturing, and ncarly everything. More fundamentally, the firm is not the basic unit of the economy, as the corporation appears to be in the United States. In Taiwan, all firms, of whatever size, are embedded in networks of other firms. Therefore, in order to understand the organization of Taiwan's economy, it only makes sense to examine how firms operate in a network of other firms and how changes occur over time in qualitative terms and from the point of view of the firm owners. In this paper, we will refer to our interviews in general terms, either citing work that has concentrated on subsets of the interview material or giving examples from the firms we interview.

Using these interviews as our point of entrance into Tawan's economy, we will show that Taiwan's export-oriented encrepreneurs organized cheir early participation in Taiwan's economy through the medium of family-owned small and medium-sized firms. They had litele direct assistance from the state, although indirectly the state provided infrastructure and upstream supplies (such as electrical encrgy and petroleum), and sone state policies (such as lank reform in the mid 1950s) unimtentionally contributed to cconomic growth in the $1960 \mathrm{~s}$. These entrepreneurs also had very little direct assistance from large Taiwanese businesses, some of which received government subsidies. In the carly years, several levels of economic players (e.g., small and medium-sized firms, hig business, state-owned enterprises) coexisted with very little direct interaction among the levels. It was not until the late 1970s and early 1980s that a more or less integrated economic system cmerged, a system in which all the cconomic levels began systernatically to interact. It was at this time that the small and mediurn-sized firms became the tail that wagged the dog, the productive force around which the rest of the Taiwanese economy became progressively more organized. The large firms hegan to target the input needs of the small and medium-sized firms, and later the state planners fell in line and also began to support the infrastructure and financial needs of smaller firms. The small and medium-sized firms retained relative independence, while the rest of the sountry became increasingly intertwined with their needs.

In the early years, though, owners of small firms initially drew on their social relacionships to develop manufacturing networks that could effectively produce batches of goods on demand. From these beginnings, Taiwan's entrepreneurs began, aggressively and with

The pacer is prare of a book project in which the two duthors are engaged. Because of space limuatsons. in this paper, we use very few quocations for the interviews. For a fullef description of these interic ws and for other analyses of SMEs based on these interiews. ser Chen 1904. 1995 and Kao 1969). 
increasing sophistication, to pusition themeselyes in the glotal economy as specialists in OEM (original equipment manufacturing) proxluction of conponertes and whole gexds that were distributed and merchandised globally by non-Tanwarese firms. Because this system of production responds directly to external orders for goxts and adjusts ies prodection capabilities accordingly, we call this system of production "reflexiwe manufacturing." [t is our conclusion that the state had very limited direct influence in creating this system of production, but once it became a going concern, the state then adjusted its goals and altered its own directives to complement and further ratwnalize this system of proxluction. Our paper recounts the rise and rationalization of Tawan's system of reflexive mantateturing. In order wo have a beter understanding, we have is put this ckrekpmental process back into its historical context

\section{THE RISE OF SMALL AND MEDIUM-SIZED ENTERPRISES (SME) IN TAIWAN: THE IMPORTANCE OF THE INITIAL STAGE}

Ihe fundamental importance ot SMEs to laiwan seconony could not have been andicipated in the early years ater World War If. The legacy of the Japanese colunialism was a

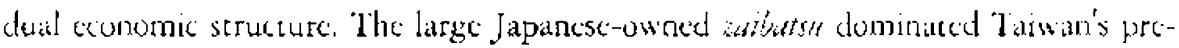
dominanty agricultural economy from the begiming of ele cotonial peried in 1805 uneil its demise in 19). 15 . Outside the state-owned sector were small Chinesc-owned businesses, which were relatively unimportant producers of manuficured goxds in Taiwan. In this reyard, they wese much like small businesses cisewhere in rhe workd economy' in the immediate post War px-riod. In 1945, China's Kuonintang governonent simply took wer the large firns that the Japanese created and made them the foundations of a large state-owned segment of the Taiwan tconomy, a scgment that continues strongly:

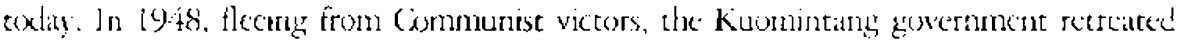
(1) Titwan and began at acarly ewenty-year effort to recurn ats military forces, consisting of a standing army of $G(0), 0(0)$ men, to Mainlani soil.

In this period, roughly from 1948 to 1568 , the nationalist government's primary groals were political and not economic. Stability in Taiwan was the tirst privrity, and the government used repression to atcain that goal. State-directed resucurces for SME development were non-cxistent. Through their conneccions to the government and their domination of the Kuomintang, Mainlanders controlled access to stace resources, and some of thes: connections were instrumental in starting a few large lousinesses, particularly party-owned busincsses in communications (e.g., newspaper, radio, and television. Also, a tew enere premeurs with state backing, such as Wang Yung clumg, tike founder of Formena Platios. stareed import substitution manufacturing.

On the whole, however, the government's expensive military and forcign policy reduced the amount of reseurces that could te used for the development of the domestic comoms. The main stibstantive conomic goal in the 1950s was to create a self-sustaining rice-basci! system of arriculture, which would be needed in the event of war and blockades. lnvoking 
the people's livelihood doctrine (mingshengimis), which is one of Sun Yatsen's People's lhree Principles, the Kuomintang government stressed relative equality within socicty and limited monopolistic tendencies in the private sector. To this end, the government embarked on land reform, reallocating land to small farners whe actually tilled the soil in exchange for non-controlling shares in a few large parry-ewned and stare-owned enterprises given to former landowners.

Iand reform created an agriculturally based frecholder econony, in which individual houscholds could decide what crops to grow and how to allocate labor and capital. Although rice remained an important staple, farmers also began to rasce other types of cash crops, so much so that agricultural products becance Iajwan's principal export sector in the 1950s, a trend that continued through the 1960 s as well, particularly during the Vietnam War, when Taiwanese farmers werc one of the primary supplicrs of fresh agricultural goods for the American forces in Viernam (Ho 1978, 198-200). "We raised lettuce," one person recalled, "but we didn't eat it."

The reminiscences of some of the earlicst successful entrepreneurs make it clear that one of the unintended consequences of land reform was to nurture a densely networked local soxiery. The Kuomintang encouraged local networks by establishing rural cooperatives and lowal party organizacions, both of which many farmers joined. At the since time, the Kumutang removed the former landlords from eronomic as well as political power. This reform was a move to consolidate their power at the local level, but it actually encouraged factionalism. Although the Kuomintang encouraged local networks, the state gave no support for non-agricultural pursuits. Nonetheless, people in rural areas began to explore other ways to expand their ability to make money beyond farming. We heard many accounts of how the earliest entrepreneurs, often the sons of farmers, had migrated for a time to nearby citics to learn skills that later became instrumental in staring their own businesses in the countryside. The capital used to star these new businesses usually came from their savings and trom family members or friends engaged in part-time: farming. Our interviews largely correspond to Tai-li Hu's accounc (1984) of her mother-in-law's rural village, Liu Ts'o, where no firms were started during the 1960 s, but where many villagers had gained sufficient skill in nearby Taichung (ity to return to Liu Ts'o in the 1970 s to establish, "all of a suddes" (H 1u 1984, 2), 20) small-scalc factories. Indeed, to (1979) makes the clain that throughout Taiwan, rural industrializarion was an extraordinarily important farure of Taiwan's economic development. Our interviesws make it clear thar the earliest cnerepreneuss, in Taichung city in the 1960 s and throughout the entire region in the 1970 s, relied hovily on raising capital and recruiting labor from the social networks that developed in the aftermath of land reform, a point also acknowledged by others as well (Ho 1978, 172.7/4; Speare 1992; Liao and Huang 1994). ${ }^{3}$ These networks based on locale and kinship enabled

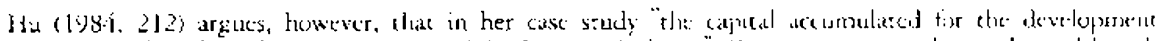
ot ru:al small-scale indistry was not mainly from agriculfure." Our irterieus indicare thas, althought

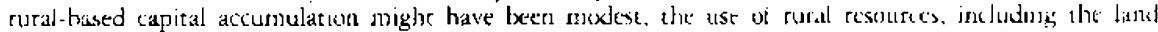

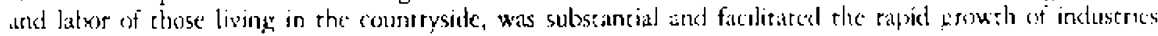
thit oceured in the 19:0s and carly 1980 s. 


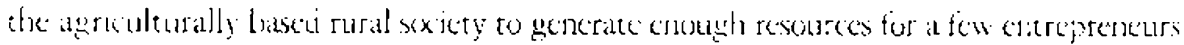

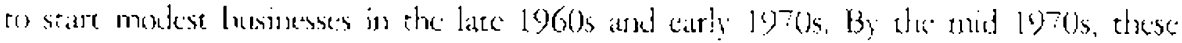

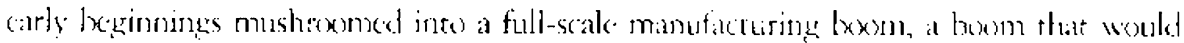
irassform "Tawain's lixal sociect.

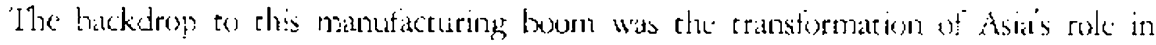
che global conomig. Deeply insolved in the Korean War as well as che Cold War. the Liniced States erecouraged Japan to rebuld their coonomy after World War ll using:

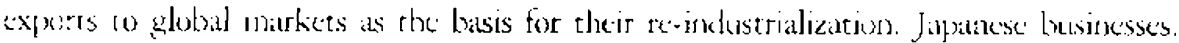

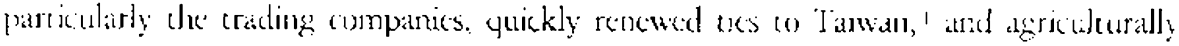

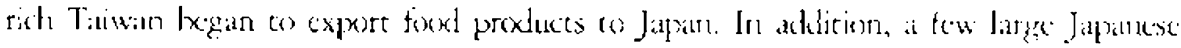

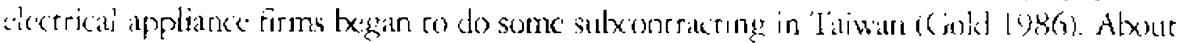

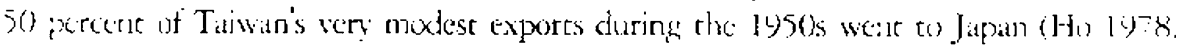

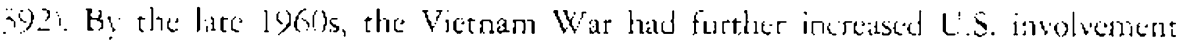

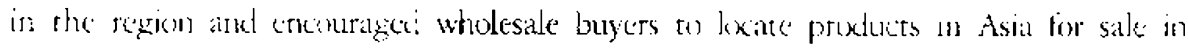

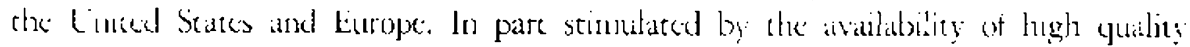

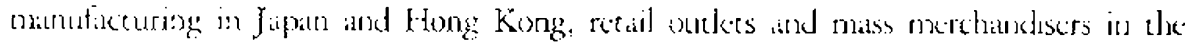
linited states ard Fursere discovered that thes could bry set amomes of manuiatured

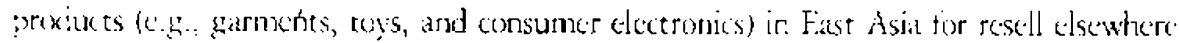
This period marked the begginning of OFM juxduction in Asia.

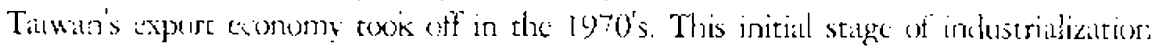

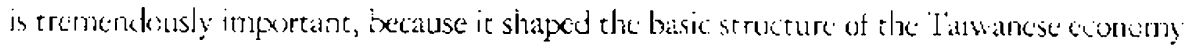

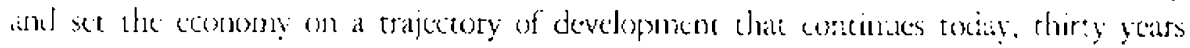

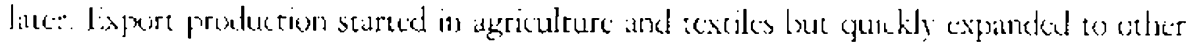

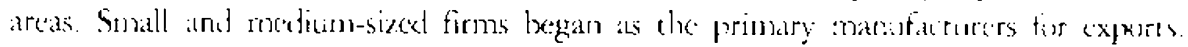
These firms could buy some of their inputs from Tidwan's import-substitating large

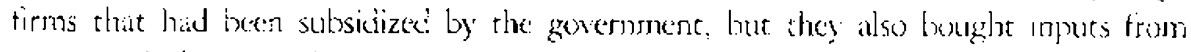
Jipars: ard the United States is well. Our intericus are clear on one point. unlike: Amseter (1985) and Eians (1995) have suggested, tivere wis never a formal ar sen long-term infermal relattonship between the upsercam prextucers of internediate goods.

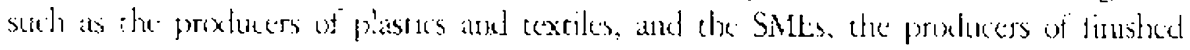

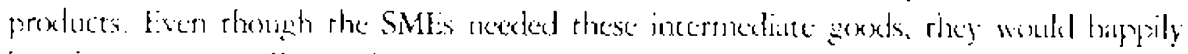

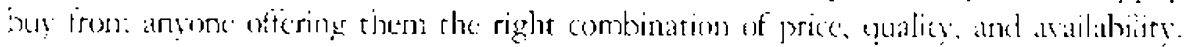

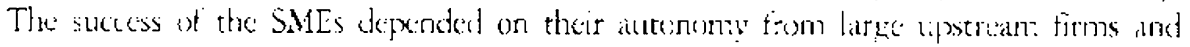
the organizalcional fexibility in linking with cach other

From the Lxyinning, smalt trading companies, cakt consisting of only a handful of

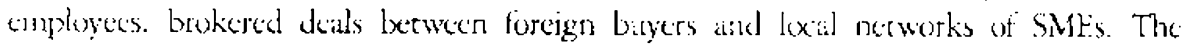

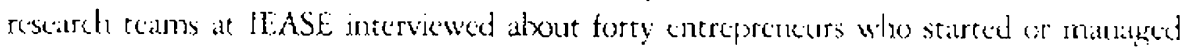

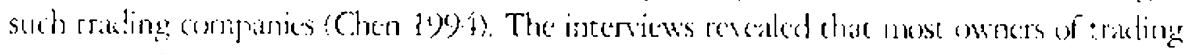

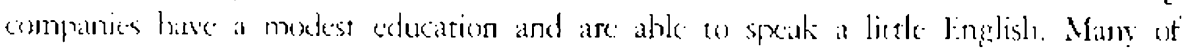

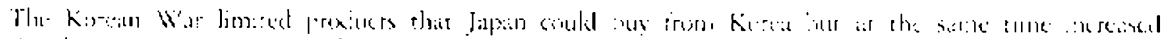

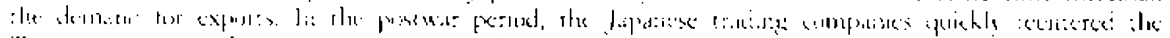

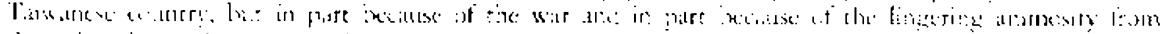

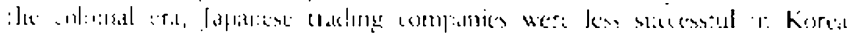


these entrepreneurs, sometimes with no advance contacts, simply wenc on the road, sample suitcase in hand, going from one wholesale firm to another in the United States and Europe. The trading companies they owned were known collogutally as pibat gungri, suitcase companies." The entrepreneurs served as compilers of information about trends in consumption, collectors of samples for reverse engineering, and as matchmakers between foreign buyers and local manufacturers. Once they had orders in hand, the traders actively participated in establishing manufacturing networks for the ordered products. Even though entrepreneurs drew on their social relationships, the production networks they put together were cemporary, functioning only as long as the contracts lasted. As such, the networks were noc static, rather their composition changed dranatically over time. As orders increased, the organizing entrepreneurs would increase theis production by subcontracting parts of the manufacturing process to others. Building around production, the networks grew more complex as the producrion became more complex. Networks segmented and proliferated, with some specializing in one type of product or a specific type of manufacturing process (e.g., metal working). Geographic concentrations grew. For instance, in the area around Hemei, in central Tawan, hundreds of firms participated in the manufacture of cotton textiles and garments (Chen, Chieh-ying 19\%). In (Chiayi, in southern Taiwan, the six hydraulic jacks plants located there dominated the world's production of hydraulic jacks.

This model of doing business was easy to learn and easy to adapr to the manufacturc of most types of products. Entry for bottom-end subcontractors was casy and required little capital. Once the process of manufacturing was mastered, a subcontraccor could venture out on his own, finding a new product to make or a better way to make an existing product. Hence, once this model of doing business was a proven success, foreign buyers began to seek out manufacturers to make the products that they wanted to merchandisc. Trade shows set up by the government helped to showeasc selected firms, but the real links between global demand and local production were the thousands of small trading companies and entrepreneurs willing to go out and find buyers (Levy [988).

By the late $1970 \mathrm{~s}$, an accelerating and self-reinforcing cycle of production had begun, fed in large part by the accelerating retail boom in the United States. By this time, the Vietnam War had ended and mass merchandising of brand-name products had begun in earnest. Many people nowadays forget that the most common brand names for consumer non-durables date only from the 1970s. Such foorwear companies as Nike and Reebok and such clothing companies as Esprit, Am Klein, and The Gap began in the 1970 as manufacturers without factories, and as designers and morchandisers they subcontracted the manufacrure of their brand name goods. Gary Gereffi (1994) terms these merchandisers and mass retailers "big huyers," and calls the types of manufacturing arrangements they established "buyer-driven commodity chains." From the outset of their deployment, Tawan, Hong Kong, and South Korea had very large shares of the big-buyer subcontracts. When such buyer-driven chains proved fatouluusly successful, Taiwan's manufacturing model became self-perpetuating. 
Whether successtul or not, Tawwan's entrepreneurs drew on their knowitedge of creadydy sociery to creatc their production networks. The knowledge they used to make the comonny work was the tacit social knowledge they already possessed. At least initially, they needed little special training to become entrepreneurs. They had, most of all, to know how to "do seciecy." This outcome was neither an intended consequence of government officials, who let loxal sexicty alone as long as there was stability and not tox much speculation, nor an intended outcome of Tajwan's big businesses, which increasingly oricnted their own business strategies to fulfilling the demands created by export-driven SMFs. Instead, the nerwork organization of 'lawan's economy rested sejuardy on the parterns of acrivity reconstructed from the patterras of Tawan's loxal sociecy.

\section{THE ECONOMIC ORGAVIZATION OF THE SMES: IHE CONNECIIIONS OF GLOBAL ECONOMY}

It would be a mistake, however, to conclude that the organization of Iaiwan s economy is due simply and entirely to its embeddedness in Taiwanese society. Sxilal institutions cereainly shaped these necworks by giving them everyday soxial meatnings as well as a style-of-life orientation (Chen 1994, 1995). But when these networks becane the medium of a system of production that could suceessfully compete in the global economy, the network organization grew increasingly economic and increasingly directid towards improving the global competitiveness of entreprencurs. The interviews with entrepreneurs make this point very dearly: They are nor in business in order to "do socicts" if.c. "to be sociable"), but rather they were "scriable" in order to makic moncy from their business. They are businesspenple first and foremost, and as businesspecople, they are not only socially embedded, but also economically conledded in a system of production in which they are players and in which they can be entrepreneurs, but uver which they have very litele control.

Secn is this way, the network organization of the Iawan economy has two levels of activity: the activities of entrepreneurs and their firms and the activicies of neivorks. Entreprencurs and their firms are not autonomous aceors, but rather are collective playcrs in a system of proxtuction, a system they laclpxat create and of which they are a proxhur. Soxially, such firms are, ipso fato, family firms because these entrepreneurs are part of a society in which family and kinship relationships form the organizarional medium by which all activitics outside of the state splere are oryanized (Fei 1902: Hamiton 1899). The heads of such businesses are Lushan, a word conventionally transiated as "bess." But habon? means more than a loss; it nueans the persin in charge. "Ihe he'ad of Furmosa Plastic is a kookm, as is the uwner of a pedeller stand selling "rocten"

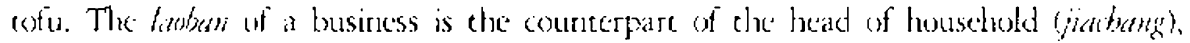
and in fact the person in charye of the business is cisually the acknowiedyed head of

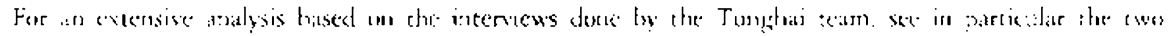

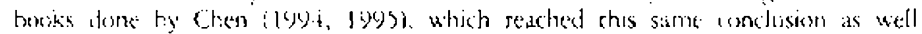


household. Therefore, business decisions are often family decisions, as Kao (1999) has demonstrated in his study of the importance of the "boss's wife" (banban mang) to the everyday operation of entrepreneurial firms, large as well as small. But a full understanding of how these firms acrually operate and transform economically is only achieved by examining how they hecome part of a system of prexluction.

In order to survive conomically, entrepreneurs must be sxcially and normatively connected co each other and more importantly, their firms must be integrited into one or more production networks. We have spent many years, through observations and interviews, trying to understand how these networks operate as economic organizations. lesoking at the networks from the entreprencurs' point of view (indluding that of the bosses' wives), we see that family units constantly leann and relean how to be a part of protuction networks. Being in a network, or networking, is a process rather than a state of being. Vetworking is part of a constantly changing economic world in which networks are dynamic vehicles through which productive activity is carriced our.

We have come to see these networks as "functional hicrarchies." The social counterpart of these economically oriented and often very specialized hierarchies is the continuing round of banquets in which all the Labon engage: The invicer hosts the meal for the invited, and all eaters observe the etiquetre of the round table, where equality and hicrarchy are subtly blended. Similarly, most proxtucrion networks consist of firms that have been invited to participate. The networks form around the: manufacture of a product. Typically, the inviting entrepreneur, often but not necessarily connected to a trading company, organizes a production network, which is made up of independent firms. Each firm corresponds to the actual requirements to manufacture a specific proxuct. Some firms may be large, some medium, and some small, depending on the inputs and manufacturing sequence. kven though in reality inequalities among entrepremeuts may be considerable, in a formal sense, every firm in the network is independene and every lewhen an independent operator. Ilowever, for cach production nctwork, there is an organizer, who invites others in, who serves as a host, who comrdinares the activitics of the network, and who serves as the person in charge.

For products having large and long-term orders, mantarturing nctworks typically grow bettor at networking and often are guite stable over time. Firns increase their technological sophistication; inefficient firms are weeded! out tactfully, and more cfficiont firms are integrated into the network. For short-term orders, production networks form and reform around each new order and each new product being proxluced. Network organizers also shift over time. Having experience as a subcontractor, an entreprencur may iry his hand at organizing a new production network around the same or similar products. Viewed from the standpoint of the economy as a whole, the dynamisn and flexibility of the Tawancse economy is easy to understand. The ability of the Taiwanese econony to respond quickly to changing global demands, to be reflexive manufacturers, was present carly in 'Tawan's economic development.

The networking dynamism has internal as well as external causes. The internal causes arise from a tendency of economic networking co incorporate new tirns in expanding 
areats ot froxductuon tofen through subcontracting and outsourcing) and to diversily across prendece areas ats demands change. The proliferation of firms keads to product developenent

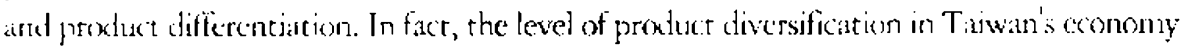
is nothing short of amazing (Feenstra, Yang, and Hanilton lyey). (xen when compared wirly much latger economies, such as South Korea and, for some proluct areas, ceven Japan. It should be noted that government support is not arnong the internal causes. The government has provided the SMEs no protection, iew privilege, and litele guidance. The gowernment has provided a friendly environment and limited support tor the developrnente of selected upstream and midstream industries. But SML's export successes, their organizational flexibility, and their manuacturing capacitics canmot be aderuately

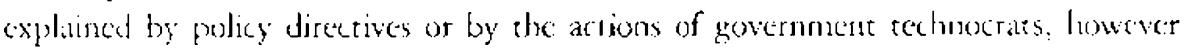

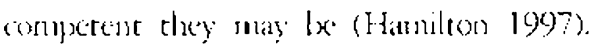

The extereal causes of Taiwan's nerworking flexibility and dunamism are equally inuportant ti) and complementary with, the incernal ones. These causes are directly linked to the grobal conomy and to the rationalizing pressure constantly placed on the organization ot the economy. We can understand the pressure towards rationalization by understanding price structute within which Taiwan's necworks function. Although the entrepreneurs nay want to increase their protics owe the long terni, the real pressure : (o rationalize prexluction networks usually comes from the lig buyers, who find thenselves in global counexition with orher merchandisers offering similar protucts. The big budyers constiontly squeeze prodliction networks with each new round of orders, and the funcrional hierarchics respond by further rationalizing their production chains. In this sense, networking and price structures are intimately linked and integral to the same economic system. As we will discuss in the next section, production networks frequently reach a point where no further systemizarion will allow the networks to reach the price targets set by outside buyers within an acceptable level of protit as demancled by parricipating

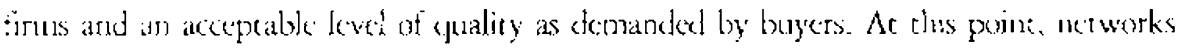
(o)llapse and are only reestablished under very differene circumstances, such als prexheucing differene produces or producing the same products under very differene conditions of prodiction.

\section{THE POST-PLAZA ACCORD IRANSFORMATION OF IAIWAN'S ECONOMY}

It the 12 years between the signing of the Plazal Accord in 6985 and the onset of the Asian business crisis in 199? Tawan's ecomm was transtormed. In this periexl, 'I iawan wene from lxing one of the world's leating exporters of fextwear and garments

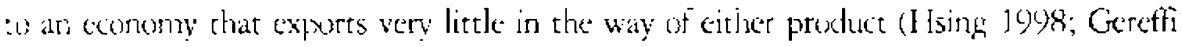
19y) it. In the sime perios. 'laiwan became one of the world's leading manufacturers it an amaing array of high technology products. From the late 1980) to early 1990s, Ianwan also experienced is severe crisis and energed trom that crisis as one of the 
world's most tesilient and dynanic economies, an economy specializing in reflexive manufacturing. It was this reflexivity that allowed Tawan to emerge relatively unsathed from the 1997 crisis that forced most other Asias economies into near bankruprcy.

In the twenty-year period between the late 1960s and the late 1980s. Taiwar's economy flourished. Early on, OEM manufacturing was very proficable and an exceedingly wide range of products came to be manufactured in Taiwan's production netwotks. As the years passed, the production teams had to work harder and harder to maintain the same level of income. Networks could only absorb so many accelerating demands from the global markets. And within Taiwan, every successtul sector of production had also generated many competing networks, which, when arded to competition from other locations in Asia, only made matters worse. Production networks could not indefinitely custion declining profits.

This complaint about declining profits and unending work were ubiquitous themes from our interviews during this period. But other factors influenced Tawan's economic covironment at this time. By the late 1980s, demographic thanges in Taiwan's society wete having a full effect on its exonomy. Family planning had bern so successful that the birth rate dropped precipirously. At the same time that the birthrate was falling, the government extended the length of mandatory education through 12 grades, further keeping peoplc out of the labor force, and those entering the labor force with education often wanted new types of jobs. Accordingly, the labor market tightened as fewer and tewer young people entered the labor force at the bottom rungs. Additionally, the government directives banning the entry of foreign laborers did nor help to alleviate the problem. The rate of unemployment reached the lowest point ever just as the demand for cheap labor increased.

After years of nunning trade deficits with Korea, Japan and Taiwan, the United States negotiated a currency reform measure and, in 1985, all parties signed at the Plaza Hotel in New York City. The Plaza Accord, as this currency reform became known, removed the pegged trading range of East Asian currencies with the U.S. dollar and allowed the Asian currencies to appreciate. In a year's period, Tajwanis currency nuoved from 40 New Taiwan dollars to 1 U.S. dollar to 27 New Taiwan dollars to 1 U.S. dollar. The recvaluation had an inmediate effect on the cross-market price structure within Taiwan's economy. Momentarily everyone was much richer as computed in U.S. dollars. The price of imports fell considerably, and local consumption and styles of life rose quickly. Real estatc prices, which had been rising, now took off, and moncy poured into property construction. Stock market speculacion also increascd.

After a short lag time, however, the cost of labor in Tawan grew probibitively lugh and accordingly Taiwan exports became more expensive on world markets. By the late 1980s, the real cstate bubble burst, the stock market collapsed from a higl of about 14,000 to a listle over 2,000, and rising exports began to taper off. Suddenly, in 1988 , Taiwan's uutward investmene skyrocketed. In a rwo-year period, 1988-90, Taiwan's most profitable manufacturers--those specializing in footwear, textiles, and garments--were out of business or moved the site of their assembly operations to China and Southeast Asia. Those entrepreneurs who stayed if Taiwan began to look for new 
proklucis a marsutiacture.

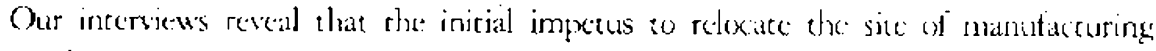
(aime from the big buyers (i.c., brand manufieturers, stot) as Nikc, and mass recailers, such as l lome Depor), who told their manufacturers to mone or lose their contrats. There was no govetrment policy that encouraged this movement or assisced it in any Way. Quite to the contrary, the govemment forbade the eranster of funds as the PRC. The owners of the SWLs, however, openly ignored the governmental restrictions atnd moved luge amouns of capital, machinery, and interrnediate irlputs es China by transshipping them though Hong Kong. Once a core group of entreprencurs began co move.

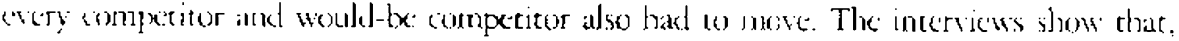

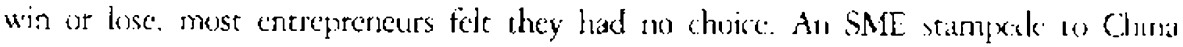
"nsued, and as som as the S.MFs had established a China bakthearl, some o: "lidwari's large tirms, supplying intermediate inputs to the small tirns. hegan te set up subsictiary tirms in China, $t(x)$. Having greatet control over large firms, the guvermient, hemescer. wis able wo block many large firms from moving.

Once is: China, Faiwanese entrepreneurs found they could nue duplicate che production metworks they had had in Taiwan. Similar to Hsing's findings (19)8), our intervicus with Taiwanesc firms in Guangdong Province show that they were forced to integratec many of the operations in the transplanted firm that hat been sonc formerly by independent tirms in the network. Qhate a few entreprercurs, especially those nuaking forweat and garments, had to establish factories in China many times the size and enploying many times the workers than they had done is Taiwars. The salc of production meant that ihey needed massive amounts of intermediate inplats, much of which they continued to buy from manufacturers in 'lawan. Accordingly, lawwan's exports to Hong Kung and then transshipped to China zoomed upward. Many firms kept thes headefuarters in Taiwats, lad their manufacturing sites in China, and shipped their exports sut to the rest of the world from 1 long Kong.

\section{THE TRANSFORMATION OF TAIWAN'S REFLEXIVE MANLFACTURING}

Ihis loblowing wut of the Taiwan economy in only a rwo geas period did not, however, spell an cirs to Iawan's manufacturing boom, as one mighe lave predicted it would. Instead, atier a downturn of several years, Taiwan's manufacturing exports resunked again, more strongly than cver. How can the resumption of. and even increase in. Taiwan's manuiduring prowess bexplained? We believe that laiwan's reftexive manufacturing system best explains this remarkable restructuring that has wecurred in the lasit detake.

Incenicus show that Titwan's entrepreneurs followed one of two strategies to upgrade their businesses. First, many entrepreneurs simply did not want to abandon their homes

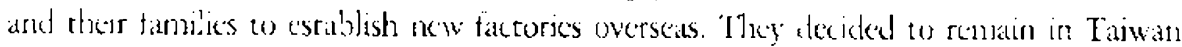
making che sank products, but now targeting the very high ested of the mathet. Where 
one firm had been making bicycles for mass consumption, it now began to make tiranium and cartxun composition bicycles for select enthusiasts who would pay pretnium prices.

The second strategy for many organizers of manufacturing networks, especially those: in traditional labor-intensive industries, was to split their business into low-end and high-end segments. They moved low-end labor-intensive segments to arcas outside of Taiwan, and resumed production on existing or new concracts in the new location. For the high-end segment, they typically tried to move production to a higher level of quality with more capital intensity than was the case previously. This often metne that they needed to find some now products to make, which were hopefilly not totally unrelated to the previous products. They wanted to retain their manufacturing cxpertise but fink a now market in which they could excel. One cntrcjereneur described his efforts as a "search and discovery mission." Entrepreneurs would read trade magazines and go to trade shows. They would travel to their markets in the Inited States and Europe to get ideas. Once they hit upon a new product, they would recombine previous resources, put together a now production network, reinvest their own money, and then begin agrain. In this search and discovery, one entrepreneur, who had made shows for twenty years, ended up successfully making high-end craft cools. Anuther entreprencur, who had made model airplanes as toys, begar making turbojets for foreign governments. In more than a few cases, however, entrepreneurs decided just to close cheir businesses, usually without formally claiming banknutcy. They sold their property and used the money to invest elsewherc.

In the late 1980s, a new period of rapid growth began, this time in high technology induscries. The entrepreneurs creating these new industries were a new group of people quite different from the first round of entreptencurs. I hese were more highly educated, many receiving their education in Tawan, but an important few had gone to scheol in the Linited States, had worked in Western high techoology firms, and then moved back to Taiwan to start businesses or manage existing ones.

This new set of entrepreneurs built on a previous high technology industry that had arisen in Taiwan in the eatly 1980s, but that had remained small and relatively unsophisticated. According to the accounts that these entrepreneurs gave us, the PC industry in Taiwan developed accidentally and with no direct assistance from the government. The government indirectly helped, however, by banning the manufacture of gambling mathines. With the government prohibition, those firms that had been making these machines necded to find something else for its production nctwork to manufacture. Drawing on their expertise, they decided to make PC clones and copics of Apple 11. When asked how he could make a computer from scratch, one entrepreneur replied with the Chinese saying, "We have no experience with horses, but we have ridden a donkey." Fron this beginning, the PC: factories in Tawan grew to become the main OEM suppliers for such American PC computer companies as Compaq and Dell. Taiwan is now the third largest manufacturer of PC related products, behind the Unired States and Japan.

The new beginning for the high technology firms occurred in the carly $1 \%$ ()s. Dentand 
in the Linted States tor computer components and peripherals wis high, and nlany

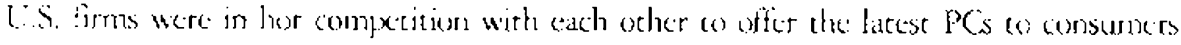
whes were just developing an appetite for fast computers with lose at memory. 'The area of decepese concentration of sofeware and hardware producers was in silion valiley. Sixenian (194). 1998) shows these producers were highly networked, and from the heginning 'I'aiw'unese and Chinese American entreperencurs had an important presence among Silicon Valley firms. Many of the hardware firms were cager to locate high cuality arad low cost OESt producers for components that had wery rapid product (yeles. Drawing on their connecions in both California and Taisan, a number uf Chinese high tech-

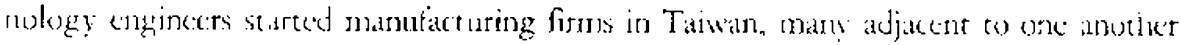
in the Hesinchu Sciconc-Based Industrial Park.

At this time, in the late 1980s, Tawan had no silion water semiconductor factory. 'The Taiwars government decided Tawan's economy needed to be compertive in high tedunolosy industries, but did nor want to compete head on with firms in the Uniced States and Japan. Private entrepreneurs (Morris Chang. a former executive at Texas Instrument, being the most prominene one persuaded gevernonent sfficials to follow

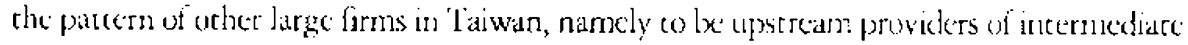
ingues that SMlis could ther use to manufacture experts. Juining wath Philips Llectronics, the gerernment cstablished Taiwan Semiconkfuctor Manditicturing (impany (TSMC). the world's first dedicated independent semiconductor manuficturing feundry. A scm-

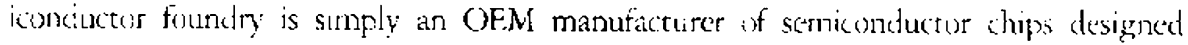
and merchandised hy other tirns, in much the same wall that griernents and footwear hatel ixen in I'awwan. In fact, TSMC's charter prevents the company "from designing or making our owin brand-naime lC products. IS.MC theretore is as partner, not a competitor with other scuiconkuctor companies." (TSMC Annual Report 1\%) ? ?)

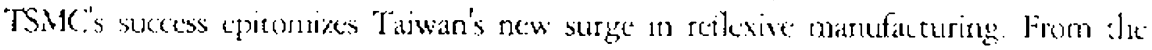

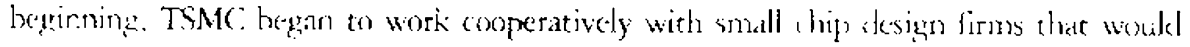
ceare special purpose chip sets for expore products. The design firms, in turn, worked with expert manufacturiog firms, some lexated in Tilnan and seme elsewhers. The key feature of the semiconductor foundry business is its integrarjor into a marufateturing system whose foremost characteristic is its quick response to extcrnal demand, the essence of reit exive manutiacturing. The approach proved successtul, and sexn uther entrepreneurs stareed toundrics in competition with TSMC. Ihe foundry business took oti. Today, semiconducer foundries form an extremely important segment in global high technology

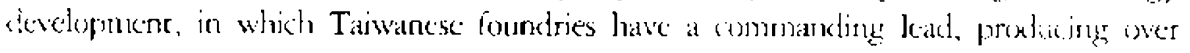
80 perecent it the grlobal demand in foundry-made chips. W'ith toundries, cuevy high techmology firm can have their own "vireual fab." They can be designers and mer-

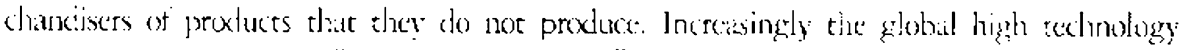

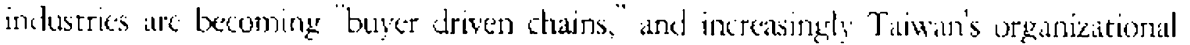
capacity: for reflexive manutacturing has pushed global thigh technology in this dircction.

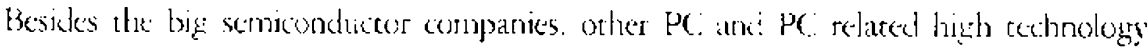

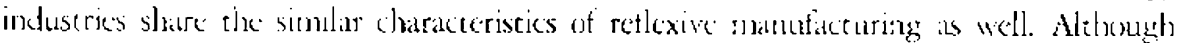


they are new firms, we also see many continuities in the pattorns of network production between the newer and the older industries. We want o be dear here: Taiwanese high-tech companics are not organized in exactly the same manner as they were with footwear and other similar products. Nonetheless, decentralized but well-connccted production nerworks serve as the basic organizational patcern in both the new and old industrics. Businesses in Taiwan are accustomed to decentralyzed networking instead of vercical integration. The major difference in the high technology industry is that the entrepreneurs are more highly professionalized than they were in the previous networks of laobai. Notwithstanding this difference, it is still apparent that there is an affinity between the global high technology industry and network production systems. It is not surprising, thereforc, that Tawanese manufacturers played such at important past in the formation of this industry. The Taiwanese entrepreneurs have mobilized the existing local conditions and efficiently integrated them into the global division of labur. They are able to achicve mass production and flexibility simultaneously. It is the transformed nerwork production system that makes reflexive manufacturing possible and successtiul.

A final word is needed about the role of the state in the development of high technology industries. Unlike in the older industries, in the new ligh technology industries the state plays a more active role, but that role is still largely restriced to providing infrastructure, for instance in the form of developing science parks, and investment capital for large, capital intensive endeavors that scrve as upstreatn suppliers of intermediate inpurs for export manufacturers. In this role, the Taiwanese state does nor act like the mythical "developmental scace" so often discussed in the literature, but rather reacts to, and is merely a sustainer of, the reflexive manufacturing system that is well institutionalized and that powers Taiwan forward.

\section{CONCLUSION}

What you see depends on where you look. In this paper, using the insights we have gained from twelve years of intensive intervicws, we have looked at the organization ot 'Taiwan's economy from the point of view of those who organize it, the entreprenturial owners and managers of firms. Based on our interviews. Taiwan's entreproneurs do now see the government as their partner. State planners are often more than willing to takic credit for laiwan's spectacular industrial successes, and some are even willing to call Taiwan's capitalist transformation an economic mirack. But the entreprenturs interviewed by the research teams at IEASE never used the word "miracle" to descritx. what they have done and they see very little governmental effects on the products of their labor. Most entrepreneurs ignored government programs and complied with government regulations only if it was convenient to do so. Iheir world is a world of business and for then the government is largely outside of this world, and is certainly: not its shaper.

Analyzing their words and actions, we have come to understand that the contrepreneur's 


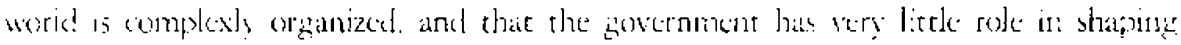
:t. The organizations of 'Tawaris economy is shaped by the striat and comomic lite

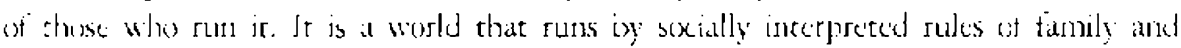

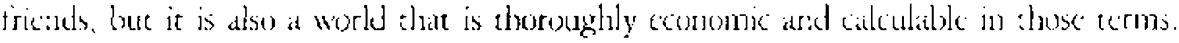

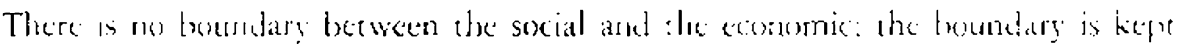

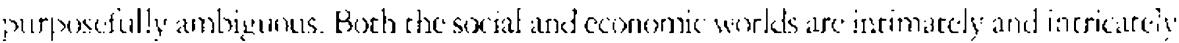

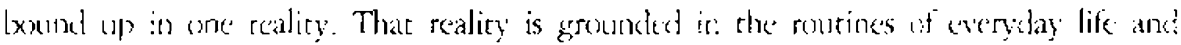

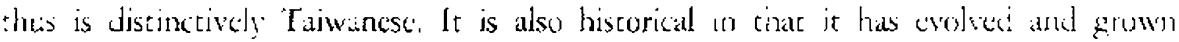

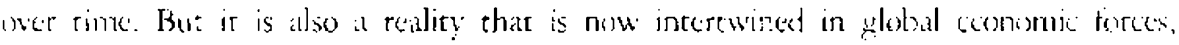

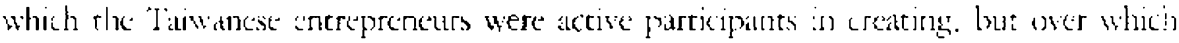

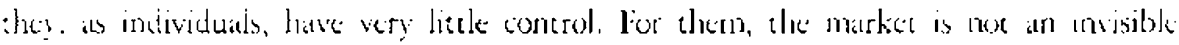

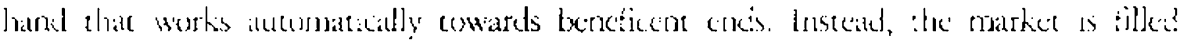

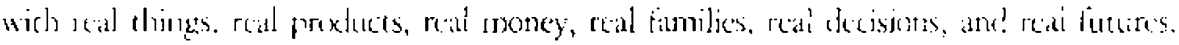

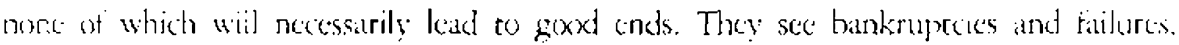
as wedt as wealeh and suceesses, all around them. Ihey know that the paths to wealet and sucess are the tried and tested. and have become instirucionalized processts in

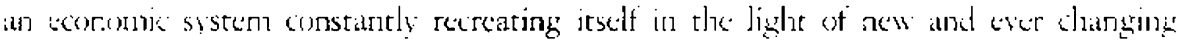
wars to molke monney. This ercompassing economic system. which constitutes the worle!

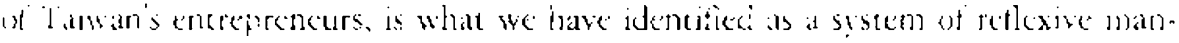

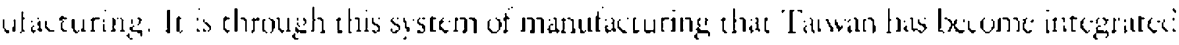
inse: tlis gristral econsury.

\section{REFERENCES}

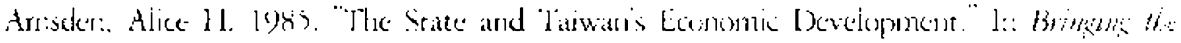

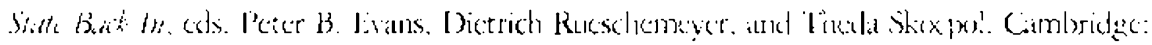
Carnloridace Linisority Press

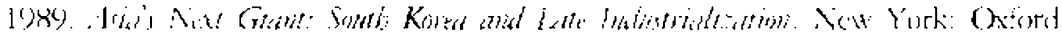
Linversity Press.

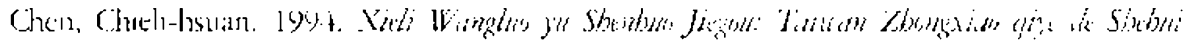

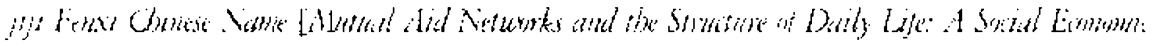

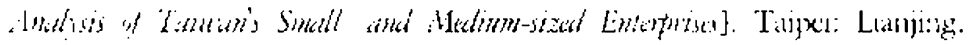

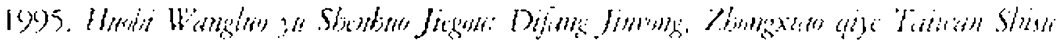

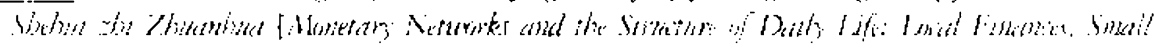

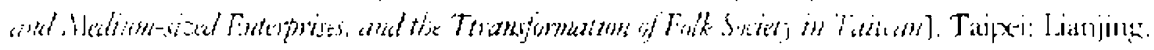

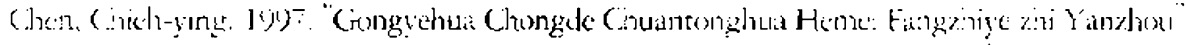

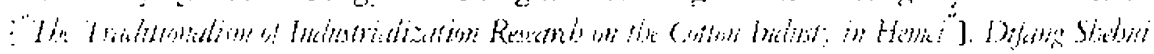

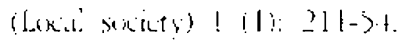

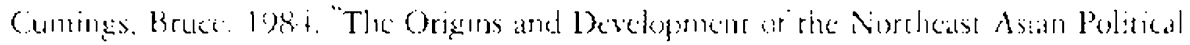

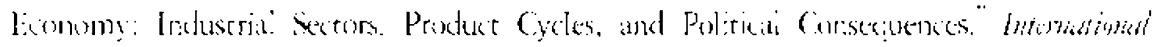

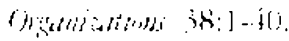

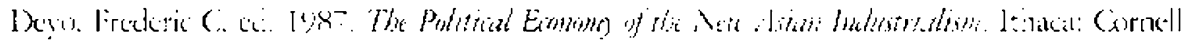


Liniversity Press.

Evans, Peter B. 1995. Embeddud ditongmy; States and isdestrial Thanformatims. Princeton, N.J.: Princecon University Press.

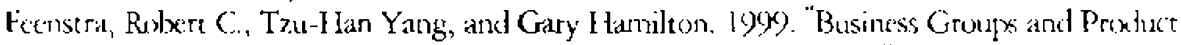
Variety in Trade: Evidence from South Korea, Taiwan and Japan."Jonmal of Iutomutiomal Exymmis 48 (June): 71-100.

lields, Karl. J. 1995. Enterpnse and the State in Kertas and Tamum. Ithaca, Vew York: Cornell Liniversity Press.

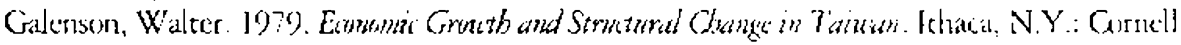
Lniversity Press.

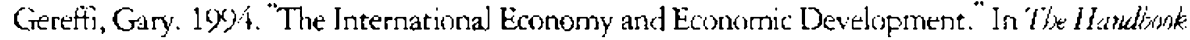
of Enmonic Sxiglog, eds. Neil Smelser and Richard Swedlxerg. Princeton: Princeton Lniversicy Press.

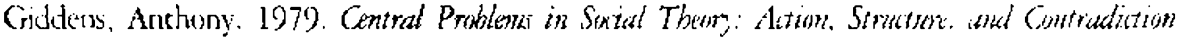
in Sacial Analysis. Berkeley: Lniversity of Californis Press.

Gold, Thomas B. 1986. Stats and Sacty in the Tawan Nlivate. Armunk, New York: M.E. Sharpe.

I laggaral, Stephan, Sylvia Maxtield, and Ben Ross Silneider. 1947. "llherries of Business

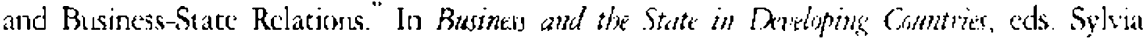
Maxfield and Ben Ross Schneider. Ithaca. N.Y.: Cornell Lniversiry Press.

Hamiloon, (Gary G. 1997. "Organization and Market Processes in Táwan's Capitalist Economy." In The Economic (hyanization of Fast Arian Capitalim, eds. Marco Orr. Nicole Worlsey Biggart, and Gary G. I lamilon. Thousand Hills: Sage Publications.

16999. "Reciprocity and Control: The Organization of Chirese liamily-owned Comglonerates." In The Globalisation of Chinese Buszess Firms, cds. Henry Wrai-chung Youngr and Kris Olds. London: Macmillan.

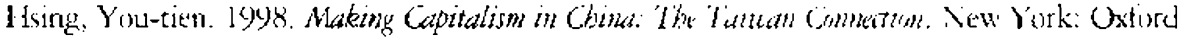
liniversity Press.

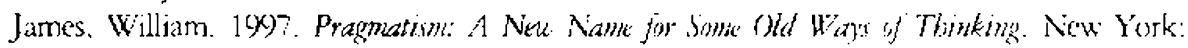
bengmans, Gircen, and Co.

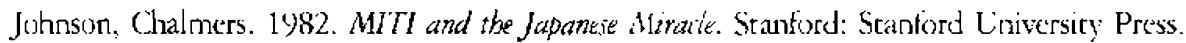
Kav, Cheng-shu. 19x9. Tomgia Niang. Taiper: Lien Chin Publishing (i).

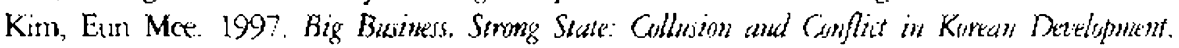
Albany: State Unversity of New York Press.

, ed. 1998. Four Asian Tigers; Economic Develupment and the Glohal political Eirmom, New York: Academic Press.

Kim, Hyuk-Rac. 19)3. "Divergent Organizational Paths of Industrialization in East Asia." Aimen Penturtice 17: 105-35.

149.1. "The State and Economic Organization in a Comparative Perspctive: The

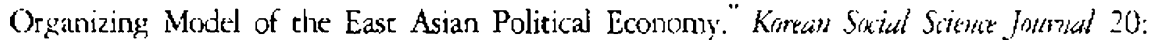
91-120.

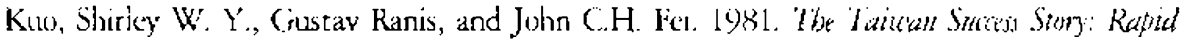

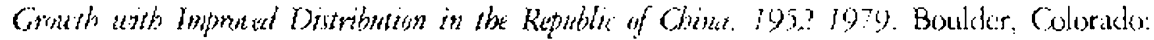
Westricw Press

Iery, Brian. 1988. "Korean and Taiwanese Firms as Internarional (ompretitors: The Challenges

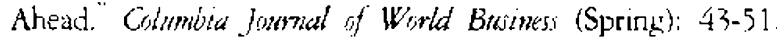




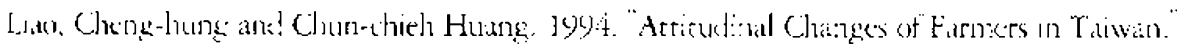

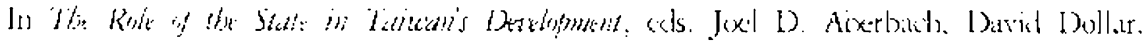

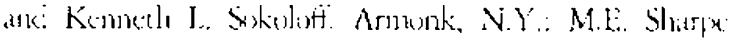

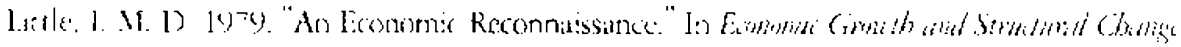

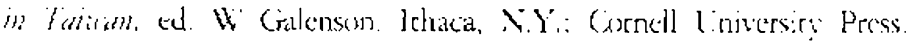

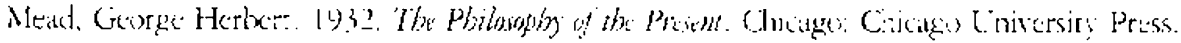

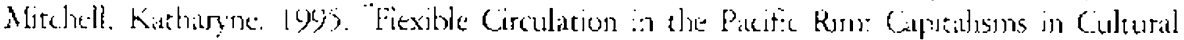

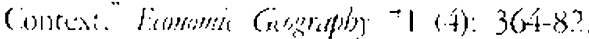

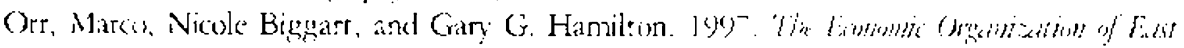
Amon Captalism. "Thousand Hills, Cailit: Sage.

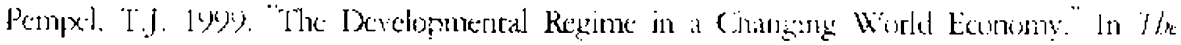

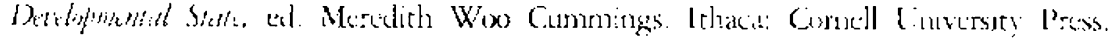

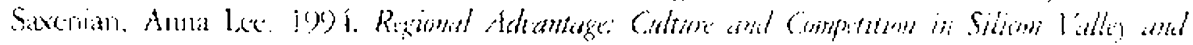

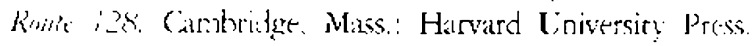

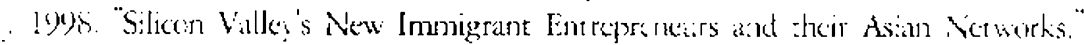

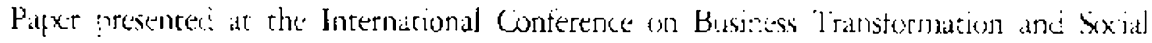
Change in Ease Asid, thay 2223, Tunghal Linsersity, Tawan.

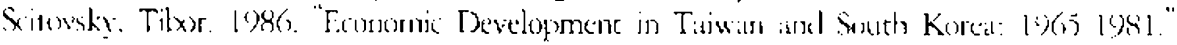

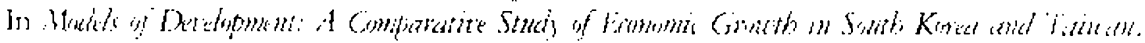

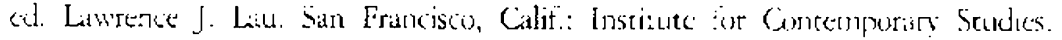

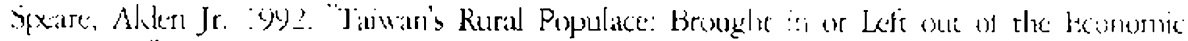

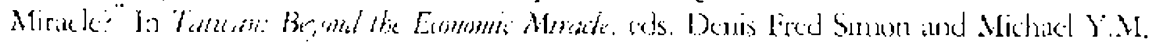

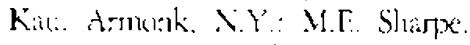

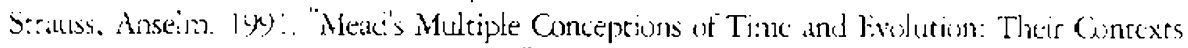

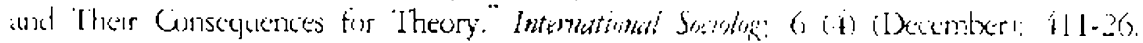

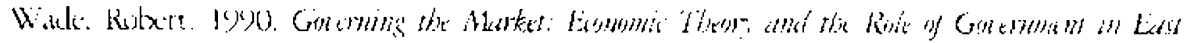

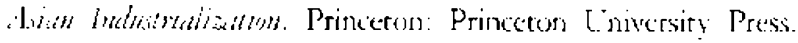

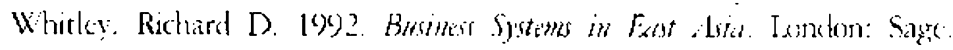

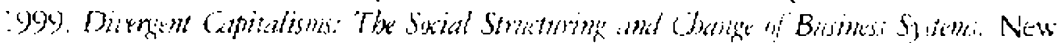
rork: Oxford Liniversity Press.

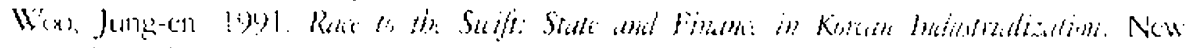
Yori: (d) lumbin I niversity Press.

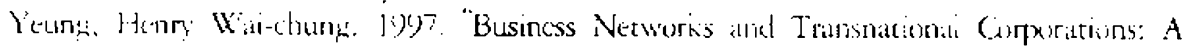

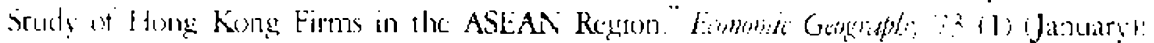
125.

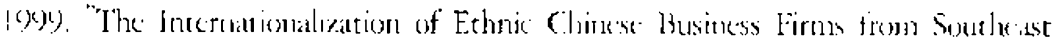

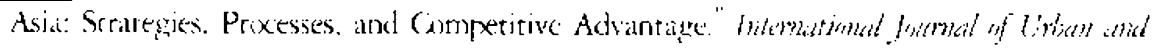

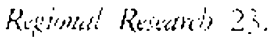

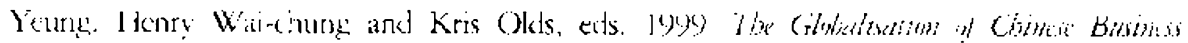

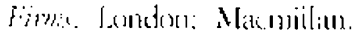

